\title{
Palaeobiodiversity of a floodplain lake sediments (N Poland) - primary and secondary factors shaping sub-fossil assemblages
}

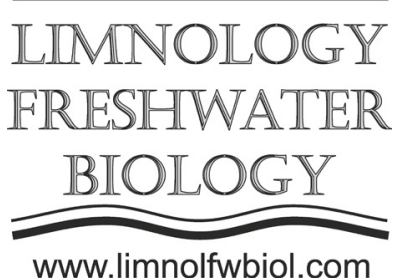

\author{
Janik E. ${ }^{1 *}$, Gadziszewska J. ${ }^{1,2}$, Niska M. ${ }^{2}$, Latałowa M. ${ }^{1}$ \\ ${ }^{1}$ Laboratory of Palaeoecology and Archeobotany, Department of Plant Ecology, University of Gdańsk, Wita Stwosza Str., 59, Gdańsk, \\ 80-308, Poland \\ ${ }^{2}$ Institute of Geography and Regional Studies, Pomeranian University in Stupsk, Partyzantów Str. 27, Stupsk, 76-200, Poland
}

\begin{abstract}
The Wrześnica 1 (W/1) site is located in the floodplain of the Wieprza River in northern Poland. Material is represented by the $890 \mathrm{~cm}$-long peat and limnic sediments dated to the Younger Dryas and the main part of the Holocene (12 700 - 3800 cal. yr BP). The multi-proxy study includes analyses of pollen with non-pollen palynomorphs (NPP's), Cladocera and plant and animal macroremains. The main purpose of the study is to reconstruct the ecological history of the wetland ecosystem and to identify factors shaping the sub-fossil assemblages of particular groups of plant and animal remains. All proxies have showed three main stages in the history of the palaeoecosystem - the lateglacial (YD) oligotrophic lake, the Holocene mesotrophic/eutrophic lake (11 750-5 600 cal. yr BP) and a mire (5 6003800 cal. yr BP). Several secondary shifts within the particular assemblages have been also described.
\end{abstract}

Keywords: palaeoecology, multi-proxy study, floodplain palaeoelake, Holocene, Late Glacial

\section{Introduction}

Using a potential of different types of data (the so-called muli-proxy) in studies on past environmental changes is actually a common and expected approach. Comparison of the results provided by different proxies allows us to understand better the processes undergoing in past ecosystems, as well as to recognize factors stimulating them (Birks and Birks 2005). However, the use of a variety of data makes interpretations of the results more complex, especially if the biostatygraphic limits are not congruent. The functioning of wetland ecosystems is the result of complex interactions between the whole range of living organisms, surrounding environment and climatic conditions. The particularly interesting objects are, in this respect, lakes located in river valleys, whose functioning depends not only on ground and rainfall waters but also on river activity. In our study we apply the data based on the analysis of sub-fossil remains of various groups of organisms found in Late Glacial and Holocene sediments of a floodplain palaeolake (ca. $12700-3800$ cal. yr BP) to reconstruct the ecological history of the lake and to identify factors shaping the sub-fossil assemblages of particular groups of plant and animal remains.

\section{Material and methods}

The Wrześnica 1 (W/1) site ( $54^{\circ} 24^{\prime} 41.5522$ " $\mathrm{N}, 16^{\circ} 43^{\prime} 59.3058^{\prime \prime} \mathrm{E}$ ) is located in the Wieprza river valley (Northern Poland, NC Europe), in the temperate transitional zone where both the Atlantic and continental impacts shape the regional climate. The $890 \mathrm{~cm}$-long profile of limnic and peat deposits was studied by pollen analysis (including non-pollen palynomorphs), Cladocera analysis and analysis of macroscopic plant and animal remains. Eleven AMS radiocarbon dates were used to develop the age-depth model.

\section{Results and conclusions}

The history of the palaeoecosystem involved three distinct stages - the lateglacial (YD) oligotrophic lake, the Holocene mesotrophic/eutrophic lake (11 750-5 600 cal. yr BP) and a mire (5 600-3 800 cal. yr $\mathrm{BP}$ ); several minor shifts within the particular stages have been also described (Fig. 1). In the present study we concentrate on the interpretations concerning (1) discrepancies in the occurrences of micro- and macroremains of the same taxa which result not only from their different resistance on fossilization

*Corresponding author.

E-mail address: ewa.golaszewska@ug.edu.pl (E. Janik) 


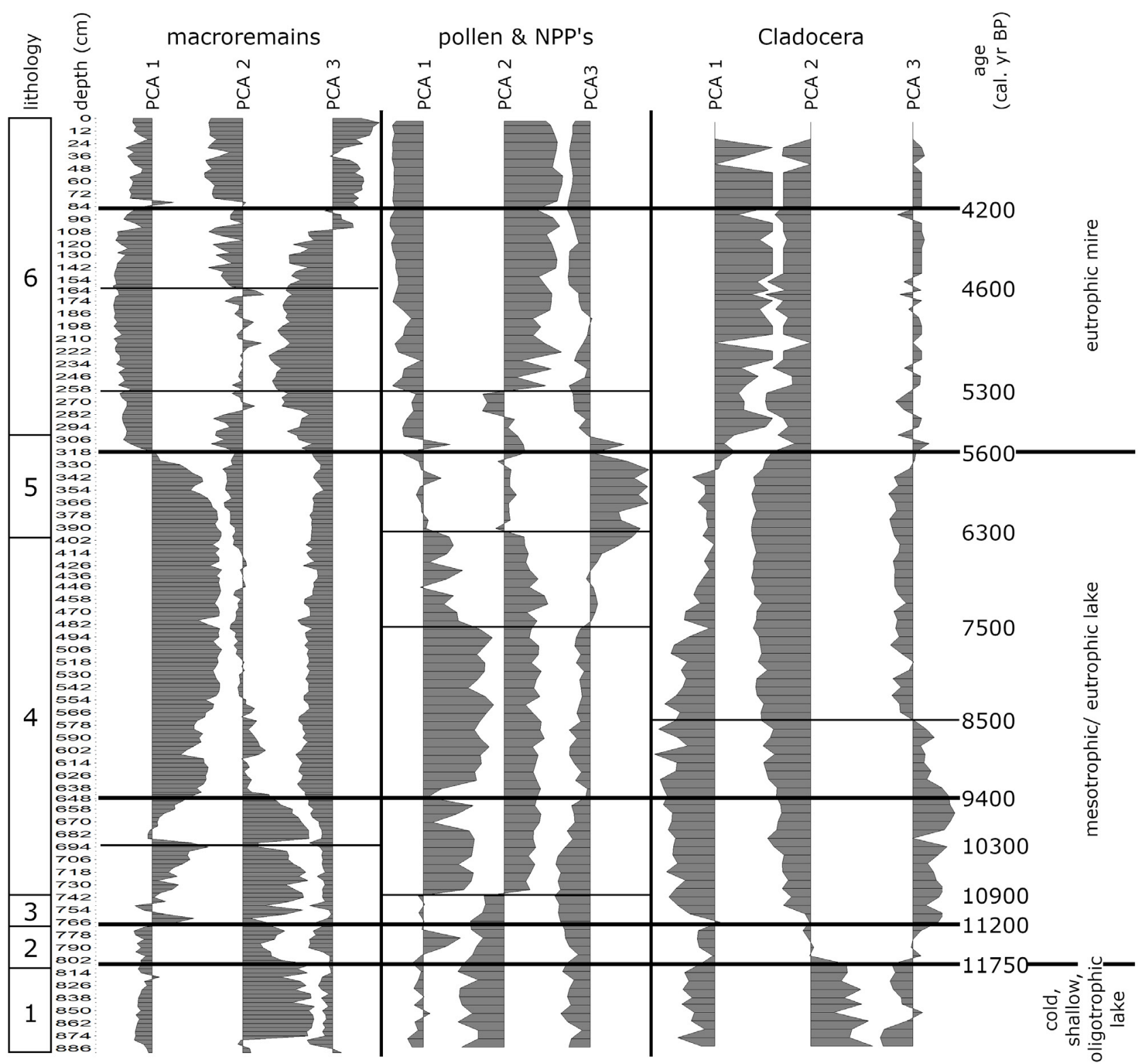

Fig.1. Results of PCA (Principal Component Analysis) in the W/1 profile; vertical lines show main changes in the course of the PCA axis for each proxy.

Lithology:

1 - silty gyttja with sand and detritus

2 - detritus gyttja with silt and sand
3 - detritus gyttja with silt

4 - detritus gyttja
5 - detritus gyttja with sand 6 - strongly decomposed peat but also on adaptations to water transport and (2) discrepancies in the locations of biostratigraphic limits executed by different groups of taxa which result from their different vulnerability to environmental factors. With this respect our results are important for better understanding of the processes shaping formation of sub-fossil assemblages in lakes. The particularly rich sub-fossil assemblages have revealed a number of plant and animal taxa which are rarely identified or have been never yet recorded in palaeoecological materials. In an earlier paper we reported on the first record of sub-fossil Orchidaceae seeds occurring abundantly in the W/1 core (Gołaszewska et al. 2019).

\section{Acknowledgements}

The research wasfinanced by the statuatory budget of the University of Gdańsk (DS 531-L145-D581-19).

\section{References}

Birks H.H., Birks H.J.B. 2006. Multi-proxy studies in palaeolimnology. Vegetation History and Archaeobotany 15: 235-251. DOI:10.1007/s00334-006-0066-6

Gołaszewska E., Gadziszewska J., Latałowa M. 2019. First record of orchid subfossil seeds - The abundant occurrence of Epipactis palustris (L.) Crantz and Dactylorhiza spp. seeds in early Holocene sediments from Central Europe. Review of Palaeobotany and Palynology 265: 1-12. DOI:10.1016/j. revpalbo.2019.03.001 